\title{
CONVERSION OF BLAST FURNACE SLAG INTO HYDROGARNET FOR HUMIC ACID REMOVAL
}

\author{
*Takaaki Wajima ${ }^{1}$ \\ ${ }^{1}$ Graduate School of Engineering, Chiba University, Japan \\ *Corresponding Author, Received: 06 Oct. 2021, Revised: 01 Dec. 2021, Accepted: 09 Jan. 2022

\begin{abstract}
The discharge of humic acid in aqueous environments is a key health and esthetic issue. In this study, blast furnace (BF) slag, a byproduct of iron- and steel-making plants, is converted into a hydrogarnet product under a hydrothermal reaction for humic acid removal. The BF slag is pulverized and passed through sieves of four different sizes, i.e., 100, 100-300, 300-500, and 500-1000 $\mu \mathrm{m}$. Subsequently, these BF slags are added to $\mathrm{NaOH}, \mathrm{KOH}$, and $\mathrm{LiOH}$ solutions with $1-4 \mathrm{M} \mathrm{NaOH}$ solution/BF slag $(=20,10$, and $4 \mathrm{~mL} / \mathrm{g})$ and heated at 80,120 , and $160^{\circ} \mathrm{C}$ for $24 \mathrm{~h}$, with or without $\mathrm{Al}(\mathrm{OH})_{3}$ addition. In the absence of $\mathrm{Al}(\mathrm{OH})_{3}$, portlandite is synthesized in alkali solutions, and the highest crystallinity of portlandite in the product is obtained in $3 \mathrm{M}$ $\mathrm{NaOH}$ at $160{ }^{\circ} \mathrm{C}$. With the addition of $\mathrm{Al}(\mathrm{OH})_{3}$, katoite, which is a hydrogarnet, as well as tobermorite and hydroxy sodalite are synthesized from $\mathrm{BF}$ slag. As the $\mathrm{NaOH}$ solution/BF slag ratio increases, the peaks of hydroxy sodalite and tobermorite increase, whereas those of katoite decrease. As the BF slag size decreases, the peaks of katoite increase because of the increase in Ca supply from the BF slag. The product, including katoite, can remove humic acid.
\end{abstract}

Keywords: Blast furnace slag, Hydrogarnet, Humic acid removal, Alkali hydrothermal synthesis

\section{INTRODUCTION}

Humic acid (HA) is a ubiquitous natural organic polyelectrolyte formed by the breakdown of animal and vegetable matter in aqueous environments. The presence of significant amounts of HA in water is indicated by a yellowish to brown color, and the chlorine used during water purification reacts with HA to form carcinogenic materials [1]. Therefore, the discharge of $\mathrm{HA}$ in water is a major environmental and health concern.

Several methods, including membrane separation and coagulation techniques, have been used to remove HA from effluents [2, 3]. Furthermore, HA can be removed from aqueous solutions via adsorption using micropores and functionalized substrate filters, which serve as adsorption sites. Inactivated carbon, the pores can be obstructed by the adsorption of HA [4]; therefore, carbon filters with mesopores were prepared to overcome this problem [5]. Meanwhile, kaolinite exhibits higher adsorption for HA than montmorillonite, although their surface functional groups (Al-OH and Si-OH) are similar [6]. The adsorption of $\mathrm{HA}$ on $\mathrm{Mg} / \mathrm{Al}$-layered double hydroxides occurs via a ligand exchange reaction with surface groups [7]. Therefore, it is believed that the binding energies of the surface functional groups significantly affect HA adsorption properties.

HA contains various organic functional groups such as hydroxyl, carboxylic, and phenolic groups, resulting in reaction sites with different potential energies. It is difficult to achieve complete removal of HA from aqueous environments because of its complex structure. Increasing the number of interactions between HA and the material surface is key to improving the adsorption properties of HA removal systems. To manipulate various adsorption sites for HA at the material surface, the hydroxyl groups must have a diverse range of binding energies. It is expected that these groups can be easily tunable as sites for reaction with $\mathrm{HA}$. The hydrogarnet series $\mathrm{Ca}_{3} \mathrm{Al}_{2}\left(\mathrm{SiO}_{4}\right)_{3-\mathrm{x}}(\mathrm{OH})_{4 \mathrm{x}}(0<\mathrm{x}<$ $3)$ is a solid solution comprising grossular $(x=0)$ and katoite $(\mathrm{x}=3)$. The increased substitution of $\left(\mathrm{SiO}_{4}\right)^{4-}$ in this structure causes a decrease in the lattice constants, resulting in disorder in the cationcentered polyhedral [8], and a hydrogarnet with several hydroxyl groups on the surface being able to adsorb HA from aqueous solutions [9].

Hydrogarnets are known as the primary hydration product in solidified cement pastes [1012]; they can be synthesized by the hydrothermal treatment of byproducts such as coal ash or molten slag [13, 14]. Blast furnace (BF) slag is the dominant byproduct of iron- and steel-making processes, and more than 23 million tons of BF slag is generated annually in Japan [15]. Although BF slag is widely used for cement production, road construction, and as a concrete aggregate, the capacity for the use of recycled BF slag in these fields has become saturated, and the development of value-added products from such waste slag has become an important issue for sustainability. Therefore, various recycling processes have been investigated recently [16, 17].

In this study, hydrogarnets were synthesized 
from BF slag using hydrothermal treatment to remove HA from aqueous solutions. Hydrogarnets were synthesized from BF slag using an alkali hydrothermal reaction, and the ability of the product to remove HA from an aqueous solution was analyzed for its possible application in wastewater treatment.

\section{EXPERIMENTAL}

\subsection{Sample}

BF slag can be classified into air- and watercooled slags, based on the cooling method. The slags contain crystalline and amorphous phases, respectively. To ensure that the phases in the slag were converted into functional phases by alkali reaction, the BF slag used in this study (received from a steel-producing plant in Japan) was watercooled. The BF slag was gently ground using a mill and sieved to less than $2 \mathrm{~mm}$. The chemical and mineralogical compositions of the raw slag were obtained via X-ray fluorescence spectrometry (Shimadzu, XRF-1700) and X-ray diffraction (XRD) (Rigaku, RINT-2500), respectively, as shown in Table 1 and Fig.1. The raw slag was composed primarily of $\mathrm{CaO}$ (42.9\%), $\mathrm{SiO}_{2}$ (34.5\%), and $\mathrm{Al}_{2} \mathrm{O}_{3}(13.7 \%)$ in the amorphous phase and minor crystalline phase, gehlenite $\left(\mathrm{Ca}_{2} \mathrm{Al}_{2} \mathrm{SiO}_{7}\right)$. Other oxides, such as $\mathrm{MgO}, \mathrm{SO}_{3}, \mathrm{Fe}_{2} \mathrm{O}_{3}, \mathrm{TiO}_{2}, \mathrm{~K}_{2} \mathrm{O}$, and $\mathrm{MnO}$, were present in lower amounts.

Table 1 Chemical composition of BF slag.

\begin{tabular}{cc}
\hline & Content (wt. \%) \\
\hline $\mathrm{CaO}$ & 42.9 \\
$\mathrm{SiO}_{2}$ & 34.5 \\
$\mathrm{Al}_{2} \mathrm{O}_{3}$ & 13.7 \\
$\mathrm{MgO}$ & 6.1 \\
$\mathrm{SO}_{3}$ & 1.1 \\
$\mathrm{Fe}_{2} \mathrm{O}_{3}$ & 0.6 \\
\hline
\end{tabular}

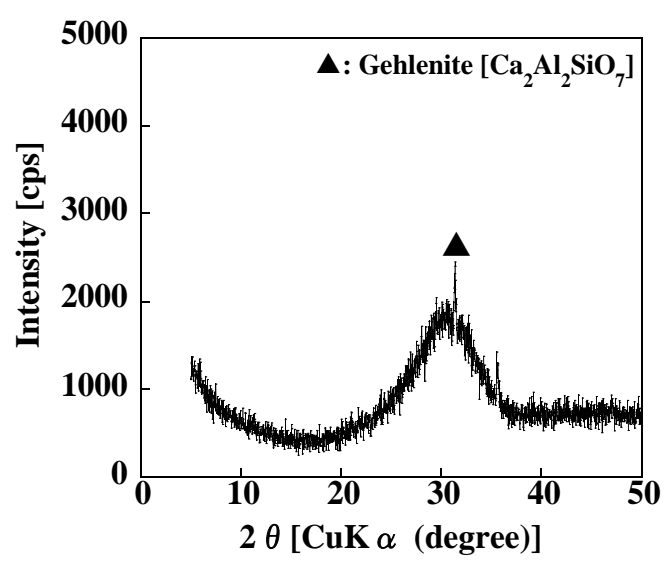

Fig.1 XRD patterns of BF slag.

\subsection{Synthesis}

The raw slag was first ground in a mill and sieved into four slags of different sizes: S-1, 100$250 \mu \mathrm{m}$; S-2, 250-500 $\mu \mathrm{m}$; S-3, 500-1000 $\mu \mathrm{m}$; and S-4, 1-2 mm. The slag $(0.5,1$, and $2.5 \mathrm{~g})$ with or without $\mathrm{Al}(\mathrm{OH}) 3$ (Wako) was added to $10 \mathrm{~mL}$ of $1-$ $4 \mathrm{M} \mathrm{NaOH}, \mathrm{KOH}$, and $\mathrm{LiOH}$ solutions in $50 \mathrm{~mL}$ pressure vessels, and heated at $80^{\circ} \mathrm{C}, 120^{\circ} \mathrm{C}$, and $160{ }^{\circ} \mathrm{C}$ for $24 \mathrm{~h}$ in an electric oven. After heating, the solid was filtered, washed with distilled water, and dried in an oven at $60^{\circ} \mathrm{C}$ overnight to obtain the product. The product phases and morphologies were analyzed using XRD. The change in the number of mineralogical phases in the product was represented as a relative crystallinity (RC) by calculation using the intensity of the major XRD peaks in the product at specified diffraction faces, i.e., portlandite ( $\left(\begin{array}{lll}0 & 0 & 1\end{array}\right)$, as follows:

$R C=\frac{(\text { Intensity of major peaks in the product })}{(\text { Intensity of major peaks in the standard })} \times 100$

Commercial $\mathrm{Ca}(\mathrm{OH})_{2}$ (Wako) were used as the standard.

\subsection{Adsorption}

The HA adsorption capacity of the product was evaluated using $0.25 \mathrm{~g} / \mathrm{L}$ of the product. The HA solution was prepared using a method first reported by Moriguchi et al. [18]. Briefly, HA was dissolved in a dilute $\mathrm{NaOH}$ solution, and the solution was filtered using a membrane filter with $0.45 \mu \mathrm{m}$ pores. Subsequently, the solution was added to a diluted $\mathrm{HCl}$ solution for precipitation and centrifuged to obtain HA. After the dissolution of the resultant HA in diluted $\mathrm{NaOH}$, dilute $\mathrm{HCl}$ was added to shift the $\mathrm{pH}$ of the HA solution to 7 to simulate real natural water. The product was soaked in HA solution at 0 $30 \mathrm{mg} / \mathrm{L}$ for $24 \mathrm{~h}$, and the supernatant obtained by centrifuging the slurry solution was analyzed via $\mathrm{UV} / \mathrm{V}$ is spectroscopy by monitoring the change in absorbance at $400 \mathrm{~nm}$. Blank samples without a product were measured for each adsorption test as a reference. The adsorption amount of HA $\left(q_{e}\right)$ was calculated using the following equation:

$q_{e}=\frac{\left(\mathrm{C}_{0}-C\right) \times V}{w}$

where $C_{0}(\mathrm{mg} / \mathrm{L})$ and $C(\mathrm{mg} / \mathrm{L})$ are the initial and measured concentrations, respectively; $V(\mathrm{~L})$ is the volume of the solution; $w$ (g) is the weight of the added sample.

\section{RESULTS AND DISCUSSION}




\subsection{HYDROGARNET SYNTHESIS}

The effects of the alkali species, concentration, and temperature on the product were investigated. It is noteworthy that $2.5 \mathrm{~g}$ of raw slag $(<2 \mathrm{~mm})$ was treated with $10 \mathrm{~mL}$ of $1-4 \mathrm{M} \mathrm{NaOH}, \mathrm{KOH}$, and $\mathrm{LiOH}$ solutions at $80^{\circ} \mathrm{C}, 120^{\circ} \mathrm{C}$, and $160{ }^{\circ} \mathrm{C}$ for 24 h. All obtained products contained portlandite $\left(\mathrm{Ca}(\mathrm{OH})_{2}\right)$ without hydrogarnets. The typical XRD patterns of the product are shown in Fig. 2.

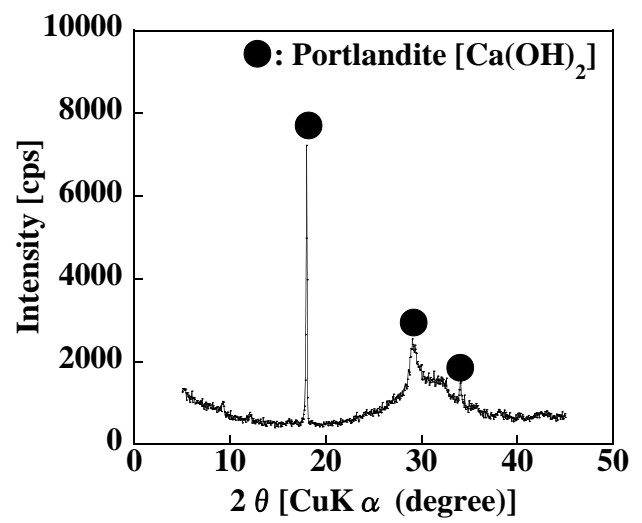

Fig. 2 XRD patterns of product from BF slag in $3 \mathrm{M}$ $\mathrm{NaOH}$ solution at $160^{\circ} \mathrm{C}$.

Figure 3 shows the RC of the portlandite phase of the product. The abscissa is the concentration of the solution, and the ordinate is the heating temperature. The white zone indicates the high crystallinity of portlandite in the product, and the black zone indicates no portlandite phase in the product. The crystallinity of portlandite in the product using $\mathrm{NaOH}$ solution was higher than that using $\mathrm{KOH}$ and $\mathrm{LiOH}$ solutions. As the $\mathrm{NaOH}$ solution and heating temperature increased (from bottom left to top right), the crystallinity of portlandite increased, and the product with the highest crystallinity of portlandite was synthesized in $3 \mathrm{M} \mathrm{NaOH}$ solution at $160{ }^{\circ} \mathrm{C}$ for $24 \mathrm{~h}$.

The effect of the solid/solution ratio on the product was determined. It is noteworthy that raw slag $(0.5,1$, and $2.5 \mathrm{~g})$ was treated with $3 \mathrm{M} \mathrm{NaOH}$ solution $(10 \mathrm{~mL})$ at $160{ }^{\circ} \mathrm{C}$ for $24 \mathrm{~h}$. The XRD patterns of the product when the solution/slag ratios were 20,10, and $5 \mathrm{~mL} / \mathrm{g}$ are shown in Fig. 4 . As the solution/slag ratio increased, tobermorite appeared in the product with portlandite, but hydrogarnet peaks were not observed.

The effect of the particle size on the product was investigated. The slag (2.5 g) with various particle sizes was treated with $3 \mathrm{M} \mathrm{NaOH}$ solution $(10 \mathrm{~mL})$ at $160{ }^{\circ} \mathrm{C}$ for $24 \mathrm{~h}$. The XRD patterns of the product from the slag with various particle sizes are shown in Fig. 5. As the particle size, tobermorite appeared in the product synthesized from the slag with particles measuring less than $500 \mu \mathrm{m}$, and katoite, one of the hydrogarnets, appeared in the product from the slag with particles measuring less than $100 \mu \mathrm{m}$.

These results indicate that hydrogarnets can be synthesized from slag particles with less than 100 $\mu \mathrm{m}$ in $3 \mathrm{M} \mathrm{NaOH}$ solution at $160^{\circ} \mathrm{C}$ for $24 \mathrm{~h}$. It is noted that the insufficient $\mathrm{Al}$ content in the solution rendered the synthesis of hydrogarnets difficult.

(a)

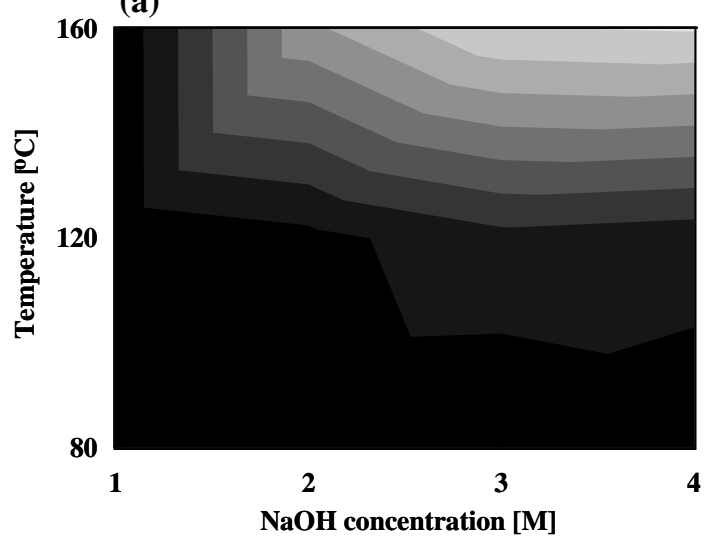

(b)

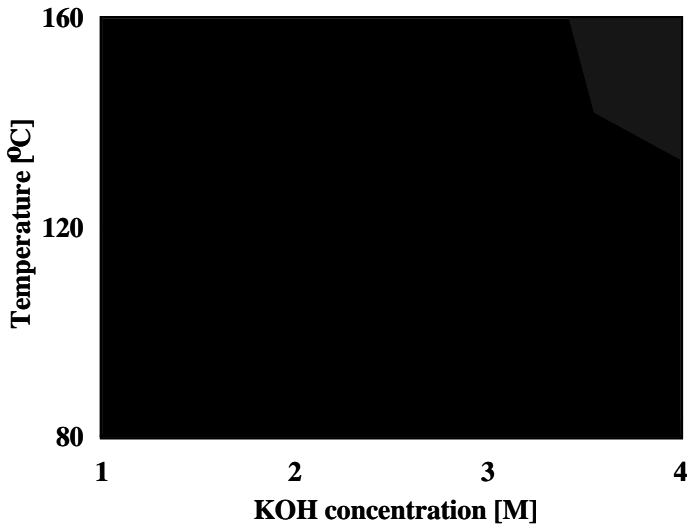

(c)

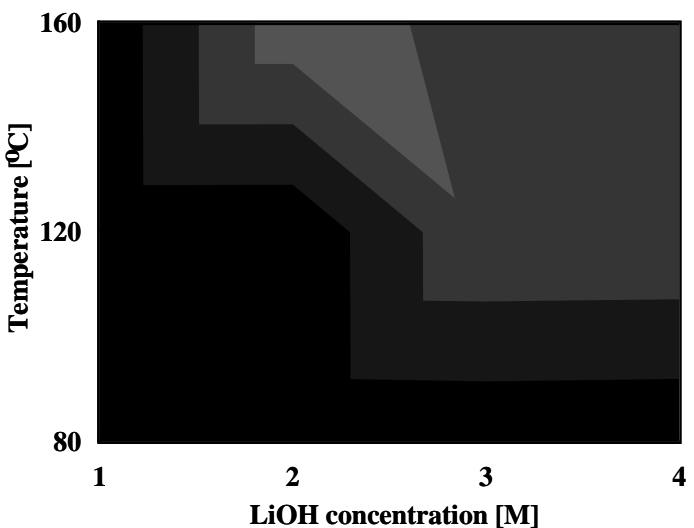

Fig.3 Crystallinity of portlandite synthesized from $\mathrm{BF}$ slag in (a) $\mathrm{NaOH}$, (b) $\mathrm{KOH}$, and (c) $\mathrm{LiOH}$ solution at various temperatures. 


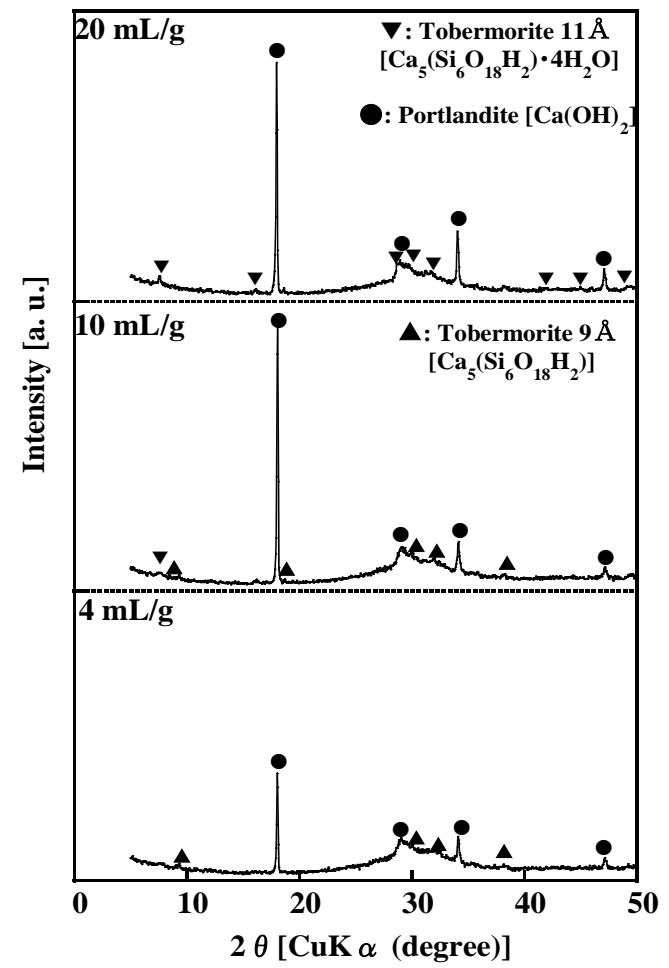

Fig.4 XRD patterns of product from BF slag in $3 \mathrm{M}$ $\mathrm{NaOH}$ solution at $160{ }^{\circ} \mathrm{C}$ when solution/slag ratios were 20,10 , and $5 \mathrm{~mL} / \mathrm{g}$.

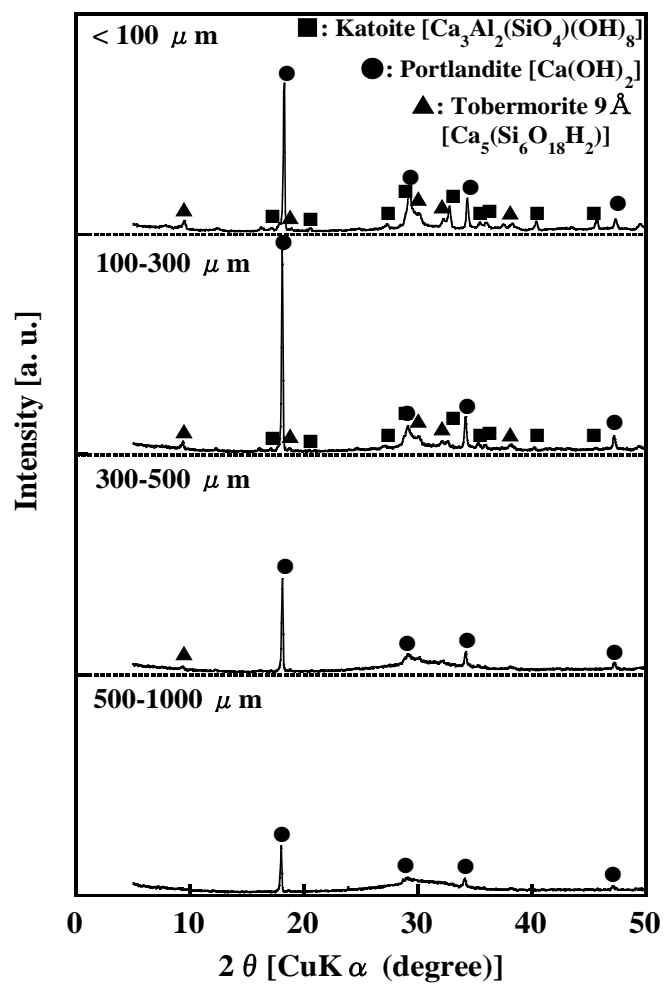

Fig.5 XRD patterns of product from BF slag with various particle sizes in $3 \mathrm{M} \mathrm{NaOH}$ solution at $160^{\circ} \mathrm{C}$.
For hydrogarnet synthesis, $2.5 \mathrm{~g}$ of slag $(<2$ $\mathrm{mm})$ and $1 \mathrm{~g}$ of $\mathrm{Al}(\mathrm{OH})_{3}$ were added to a 1-3 M $\mathrm{NaOH}$ solution $(10 \mathrm{~mL})$ at $160{ }^{\circ} \mathrm{C}$ for $24 \mathrm{~h}$. The XRD patterns of the product synthesized from the slag with $\mathrm{Al}(\mathrm{OH})_{3}$ added are shown in Fig. 6. Portlandite was synthesized in the absence of $\mathrm{Al}(\mathrm{OH})_{3}$. With the addition of $\mathrm{Al}(\mathrm{OH})_{3}$, katoite can be synthesized in the product. The peaks of katoite and boehmite were confirmed in the product synthesized in $1 \mathrm{M} \mathrm{NaOH}$ solution, and as the $\mathrm{NaOH}$ concentration increased, the peak intensity of boehmite decreased. The product containing katoite and hydroxy sodalite can be synthesized from the slag in a $3 \mathrm{M} \mathrm{NaOH}$ solution.

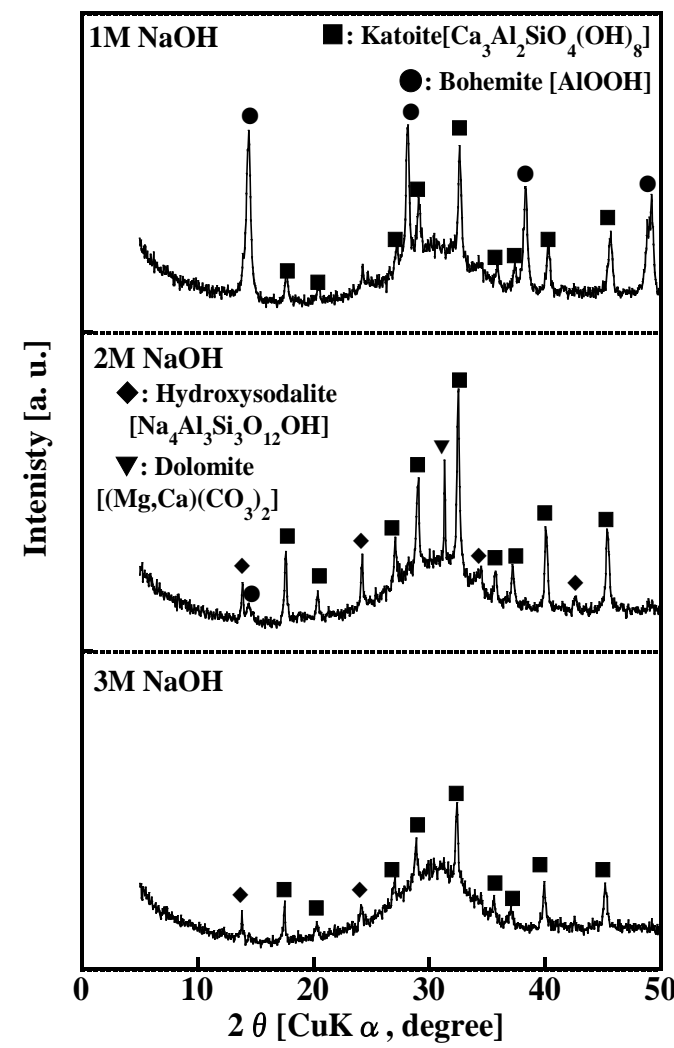

Fig.6 XRD patterns of products synthesized from $\mathrm{BF}$ slag in 1-3 $\mathrm{M} \mathrm{NaOH}$ solution at $160{ }^{\circ} \mathrm{C}$ for $24 \mathrm{~h}$ with $\mathrm{Al}(\mathrm{OH})_{3}$ added.

The effect of the solution/slag ratio on the product synthesized with $\mathrm{Al}(\mathrm{OH})_{3}$ added was investigated. The slag $(5 \mathrm{~g})$ and $\mathrm{Al}(\mathrm{OH})_{3}(2 \mathrm{~g})$ were mixed, and the mixture $(0.6,1.2$, and $3.5 \mathrm{~g})$ was treated with $3 \mathrm{M} \mathrm{NaOH}$ solution at $160{ }^{\circ} \mathrm{C}$ for $24 \mathrm{~h}$. The XRD patterns of the product synthesized from the mixture at various solution/slag ratios are shown in Fig. 7. All products contained katoite, and as the solution/slag ratio increased, the peaks of katoite decreased, whereas those of hydroxy sodalite and tobermorite increased. It was assumed that the synthesis of hydrogarnets at $4 \mathrm{~mL} / \mathrm{g}$ would yield better results than those at 10 and $20 \mathrm{~mL} / \mathrm{g}$. 


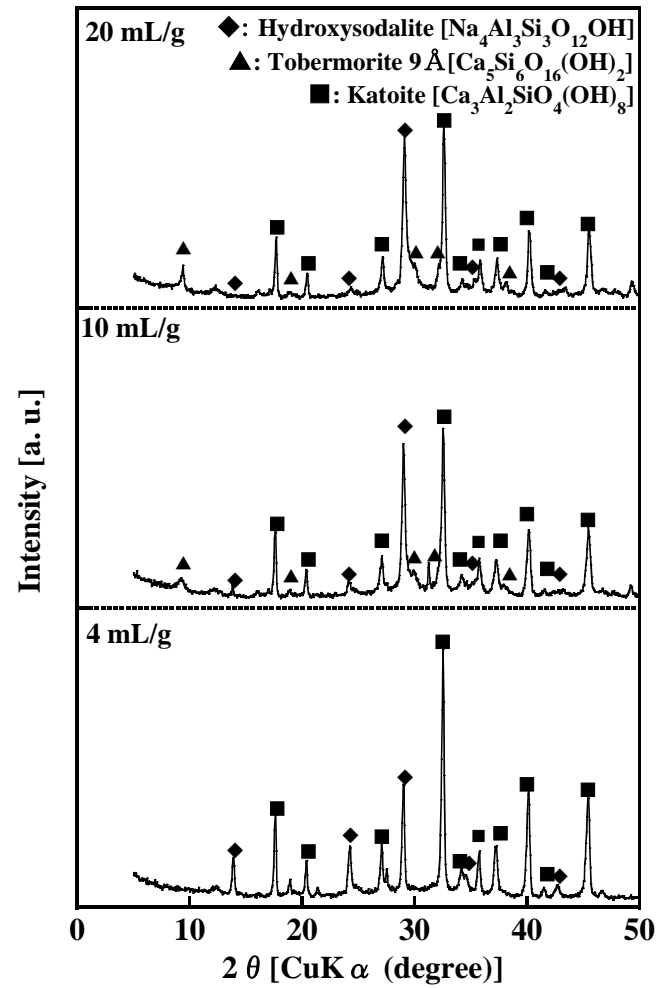

Fig.7 XRD patterns of product from BF slag with $\mathrm{Al}(\mathrm{OH})_{3}$ in $3 \mathrm{M} \mathrm{NaOH}$ solution at $160{ }^{\circ} \mathrm{C}$ for solution/slag ratios of 20,10 , and $4 \mathrm{~mL} / \mathrm{g}$.

The effect of particle size on the product synthesized with $\mathrm{Al}(\mathrm{OH})_{3}$ added was investigated. The slag (2.5 g) and $\mathrm{Al}(\mathrm{OH})_{3}(1 \mathrm{~g})$ were mixed, and the mixture was treated with $3 \mathrm{M} \mathrm{NaOH}$ solution at $160{ }^{\circ} \mathrm{C}$ for $24 \mathrm{~h}$. The XRD patterns of the product synthesized from the slag of various particle sizes with $\mathrm{Al}(\mathrm{OH})_{3}$ added are shown in Fig. 8. All products contained katoite, and as the particle size decreased, the peaks of katoite and hydroxy sodalite increased. It was assumed that the synthesis of hydrogarnets from slag with smaller particles would yield better results, due to the higher supply of $\mathrm{Ca}$ to mineral phases from smaller particles, as shown in Fig. 5.

These results suggest that the product, including hydrogarnets, can be synthesized from slag with particles measuring less than $100 \mathrm{~m}$ by adding $\mathrm{Al}(\mathrm{OH})_{3}$ in $3 \mathrm{M} \mathrm{NaOH}$ solution at $160{ }^{\circ} \mathrm{C}$ for $24 \mathrm{~h}$.

\subsection{HA Removal}

The HA adsorption of the product is shown in Fig. 9. The product was synthesized from $2.5 \mathrm{~g}$ of the slag $(<100 \mu \mathrm{m})$ with $\mathrm{Al}(\mathrm{OH})_{3}$ addition $(1 \mathrm{~g})$ in $3 \mathrm{M} \mathrm{NaOH}$ solution $(10 \mathrm{~mL})$ at $160{ }^{\circ} \mathrm{C}$ for $24 \mathrm{~h}$. As the HA concentration increased, HA adsorption increased gradually.

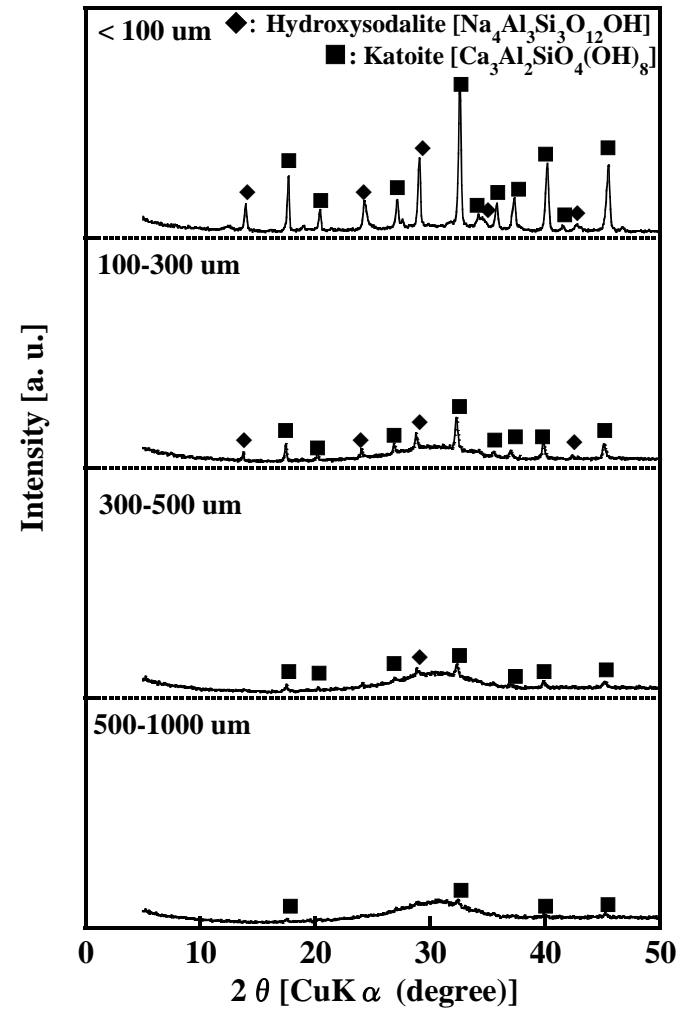

Fig.8 XRD patterns of product from a mixture of BF slag of various particle sizes and $\mathrm{Al}(\mathrm{OH})_{3}$ in $3 \mathrm{M}$ $\mathrm{NaOH}$ solution at $160^{\circ} \mathrm{C}$.

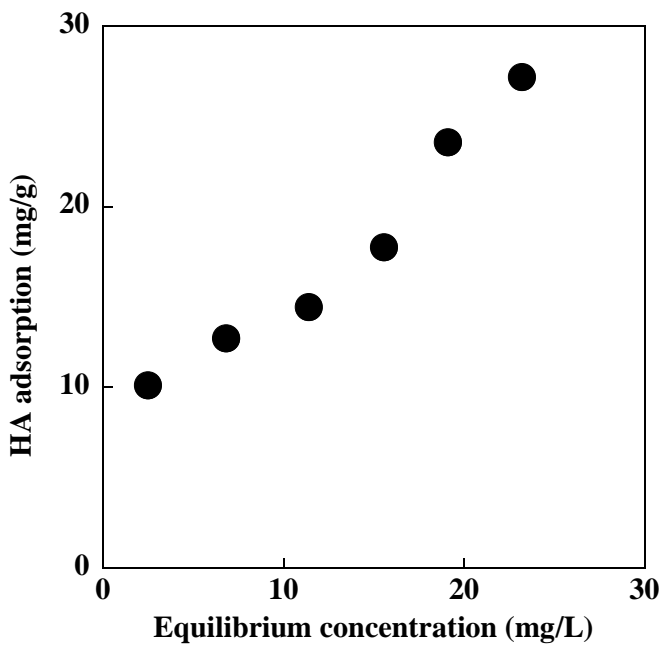

Fig.9 Isotherm of HA adsorption for the product.

The HA adsorption of the product was determined based on isotherm models. Several isotherm models can be used to describe the equilibrium sorption distribution, in which two models are used to fit the experimental data, i.e., Langmuir and Freundlich models.

The linear forms of the Langmuir and Freundlich models are expressed as follows: 


$$
\begin{aligned}
& \frac{C_{e}}{q_{e}}=\frac{1}{q_{\max } \times K_{L}}+\frac{C_{e}}{q_{\max }} \\
& \ln \left(q_{e}\right)=\ln \left(K_{F}\right)+\frac{1}{n} \ln \left(C_{e}\right)
\end{aligned}
$$

where $q_{e}$ is the HA adsorption amount at equilibrium (mg/g); $q_{\max }(\mathrm{mg} / \mathrm{g})$ and $K_{L}(\mathrm{~L} / \mathrm{mg})$ are Langmuir constants related to the maximum adsorption capacity corresponding to the complete coverage of available adsorption sites and a measure of adsorption energy (equilibrium adsorption constant), respectively. $K_{F}$ and $n$ are Freundlich constants.

The results of the isotherm analysis are presented in Table 2. Our experimental results indicate a correlation regression coefficient $\left(R^{2}\right)$, which is the measure of goodness-of-fit, of 0.975 and 0.978 when the Langmuir and Freundlich models were used, respectively. The Freundlich model indicated a better fit than the Langmuir model, as the former had a higher $R^{2}$ than the latter.

Table 2 Parameters and correlation regression for Langmuir and Freundlich models.

\begin{tabular}{cccccc}
\hline \multicolumn{3}{c}{ Langmuir } & \multicolumn{3}{c}{ Freundlich } \\
\hline$q_{\max }$ & $K_{L}$ & $R^{2}$ & $n$ & $K_{F}$ & $R^{2}$ \\
\hline 192.3 & 0.006 & 0.975 & 1.09 & 1.50 & 0.978 \\
\hline
\end{tabular}

\section{CONCLUSIONS}

BF slag was converted into a product that included hydrogarnets to remove HA from the aqueous solution. The results are summarized as follows:

-BF slag with smaller particles can be converted into a product including hydrogarnets via hydrothermal treatment with $3 \mathrm{M} \mathrm{NaOH}$ solution at $160{ }^{\circ} \mathrm{C}$ for 24 h with $\mathrm{Al}(\mathrm{OH})_{3}$ addition when the solution/slag ratio was $4 \mathrm{~mL} / \mathrm{g}$.

-The product can remove HA from an aqueous solution.

- The HA adsorption of the product was fitted to the Freundlich isotherm model.

This study demonstrated that a novel hydrogarnet-containing adsorbent capable of removing $\mathrm{HA}$ from aqueous solutions can be synthesized from BF slag through an alkali reaction with $\mathrm{Al}(\mathrm{OH})_{3}$ addition. These results suggested new recycling technology for steel making and new adsorbents for HA removal in water treatment.

\section{REFERENCES}

[1] Tang W. Z. and Tassos S., Oxidation Kinetics and Mechanisms of Trihalomethanes by Fenton's reagent, Water Res., Vol. 31, 1997, pp.1117-1125.

[2] Jucker C. and Clark M. M., Adsorption of Aquatic Humic Substances on Hydrophobic Ultrafiltration Membranes, J. Member. Sci., Vol. 97, 1994, pp. 37-52.

[3] Wei J., Gao B., Yue Q., Wang Y., Li W., and Zhu X., Comparison of Coagulation Behavior and Floc Structure Characteristic of Different Polyferric-Cationic Polymer Dual Coagulants in Humic Acid Solution, Water Res., Vol. 43, 2009, pp. 724-732.

[4] Chen J. P. and Wu S., Simultaneous Adsorption of Copper Ions and Humic Acid Onto an Activated Carbon, J. Colloid Interface Sci., Vol. 280, 2004, pp. 334-342.

[5] Libbrecht W., Verberckmores A., Thybaut J. W., Voort P. V. D., and Clercq J. D., Tunable Large Pore Mesoporous Carbons for the Enhanced Adsorption of Humic Acid, Langmuir, Vol. 33, 2017, pp. 6769-6777.

[6] Feng X., Simpson A. J. and Simpson M. J., Chemical and Mineralogical Controls on Humic Acid Sorption to Clay Mineral Surfaces, Org. Geochem., Vol. 36, 2005, pp. 1553-1566.

[7] Vreysen S. and Maes A., Adsorption Mechanism of Humic and Fulvic Acid Onto $\mathrm{Mg} / \mathrm{Al}$ Layered Double Hydroxides, Appl. Clay Sci., Vol. 38, 2008, pp. 237-249.

[8] Mercury J. M. R., Turrillas X., Aza A. H. and Pena P., Calcium Aluminates Hydration in Presence of Amorphous $\mathrm{SiO}_{2}$ at Temperatures Below $90{ }^{\circ} \mathrm{C}$, J. Solid State Chem., Vol. 179, 2006, pp. 2988-2997.

[9] Maeda H., Kurosaki Y., Nakayama M., Ishida E. H., and Kasuga T., Adsorption Behavior of Hydrogarnet for Humic Acid, R. Soc. Open Sci., Vol. 5, 2018, 172023.

[10] Kobayashi S. and Shoji T., Infrared Analysis of the Grossular-Hydrogrossular Series, Mineral. J., Vol. 11, 1982, pp. 331-343.

[11] Passaglia E. and Rinaldi R., Katoite, A New Member of the $\mathrm{Ca}_{3} \mathrm{Al}_{2}\left(\mathrm{SiO}_{4}\right)_{3}-\mathrm{Ca}_{3} \mathrm{Al}_{2}(\mathrm{OH})_{12}$ Series and a New Nomenclature for the Hydrogrossular Group of Minerals, Bull. Mineral., Vol. 107, 1984, pp. 605-618.

[12] Sacerdoti M. and Passaglia E., The Crystal Structure of Katoite and Implications Within the Hydrogrossular Group of Minerals, Bull. Mineral., Vol. 108, 1985, pp. 1-8.

[13]Fujita S., Suzuki K., and Shibasaki Y., The Mild Hydrothermal Synthesis of Hydrogrossular from Coal Ash, J. Mater. 
Cycles Waste Manage., Vol. 4, 2002, pp. 41-45. [14] Fujita S., Suzuki K., Shibasaki Y., and Mori T., Synthesis Hydrogarnet from Molten Slag and its Hydrogen Chloride Fixation Performance at High-temperature, J. Mater. Cycles Waste Manage., Vol. 4, 2002, pp. 70-76.

[15] Nippon Slag Association (NSA), The Annual Report of Statics of Iron and Steel Slag 2018, http://www.slg.jp/statistics/report.html

[16] Wajima T. and Munakata K., Synthesis of 11A Tobermorite from Blast Furnace Slag Using EDTA, J. Ion Exch., Vol. 21, 2010, pp. 171174.
[17]Wajima T., Oya K., Shibayama A., Sugawara K., and Munakta K., Synthesis of Hydrocalumite-like Adsorbent from Blast Furnace Slag Using Alkali Fusion, ISIJ Int., Vol. 51, 2011, pp. 1179-1184.

[18] Moriguchi T., Yano K., Tahara M., and Yaguchi K., Metal-modified Silica Adsorbents for Removal of Humic Substances in Water, J. Colloid Interface Sci., Vol. 283, 2005, pp. 300-310.

Copyright (C) Int. J. of GEOMATE All rights reserved, including making copies unless permission is obtained from the copyright proprietors. 